\title{
Financial and Non-Financial Barriers to Innovation and the Degree of Radicalness
}

\author{
Dragana Radicic 1
}

Lincoln International Business School, University of Lincoln, Lincoln LN6 7TS, UK; dradicic@lincoln.ac.uk

\begin{abstract}
The aim of this study is to analyse the effects of barriers to innovation on firms' propensity to engage in radical and incremental innovations. We look at innovative and potentially innovative firms and estimate the effect of three types of barriers-financial, knowledge and competition-on the propensity to radical innovation new to the world, radical innovation new to the market and incremental innovation. An empirical study has been performed, drawing on data collected from the German Mannheim Innovation Panel covering the period from 2014 to 2016. Empirical results reveal heterogeneous effects of barriers depending on the degree of radicalness. In particular, knowledge and competition barriers are an impediment to radical innovation, whereas financial and knowledge barriers reduce a probability of incremental innovation. Based on the findings, we discuss policy recommendations for mitigating barriers to innovation conditional on the degree of radicalness.
\end{abstract}

Keywords: barriers to innovation; radical innovation; incremental innovation; potential innovators

check for updates

Citation: Radicic, D. Financial and Non-Financial Barriers to Innovation and the Degree of Radicalness.

Sustainability 2021, 13, 2179. https:// doi.org/10.3390/su13042179

Academic Editor: Matteo Rossi

Received: 25 January 2021

Accepted: 15 February 2021

Published: 18 February 2021

Publisher's Note: MDPI stays neutral with regard to jurisdictional claims in published maps and institutional affiliations.

Copyright: (C) 2021 by the author. Licensee MDPI, Basel, Switzerland. This article is an open access article distributed under the terms and conditions of the Creative Commons Attribution (CC BY) license (https:// creativecommons.org/licenses/by/ $4.0 /)$.

\section{Introduction}

This study investigates the impact of financial and non-financial barriers on radical and incremental innovations in German firms. The literature on firm-level innovation can, in general, be divided into two complementary streams of research; the one focusing on drivers of innovation, and another investigating barriers to innovation. While the former is a dominant approach [1-3], more research on the latter would be beneficial, given that identifying barriers that attenuate firms' innovation activities has straightforward policy implications $[1,2,4,5]$ and can help managers in identifying and mitigating obstacles to innovation performance. Accordingly, until the 1990s, policy makers mainly focused on overcoming barriers to innovation, while afterwards, the focus shifted on providing incentives to innovation [6]. The former is associated with addressing market failures associated with innovation activities, while the latter arises from policies aimed at tackling systemic failures.

The study makes a number of contributions to the stream of research focusing on barriers to innovation: first, it adds to the debate on barriers to innovation, both financial and non-financial, in particular knowledge and competition barriers. Until recently, most theoretical and empirical studies on barriers to innovation were concerned with financial barriers. However, recent studies draw attention to other types of barriers, most notably those associated with market uncertainty and knowledge management (see, e.g., $[2,4,7,8]$ ). In this study, besides financial and knowledge barriers, we explore the effects of competition barriers to innovation. The impact of competition on innovation activities is usually explored in a separate strand of literature (see $[9,10])$, although empirical evidence is mixed. For instance, while Aghion et al. [9] report an inverted U-shaped relationship between competition and innovation, Hashmi [11] finds a mildly negative relationship. A prominent feature of these studies is that innovation is measured by patent application. We explore the effects of competition barriers on the degree of innovation radicalness, proxied by the introduction of radical and incremental innovation, rather by the number of patents that a firm filed for. 
Second, this study explores whether barriers to innovation are heterogeneous, given the degree of innovativeness. As noted by Sandberg and Aarikka-Stenroos [3] and Hueske and Guenther [12], there is a lack of studies on barriers to innovation that explore the degree of radicalness, i.e., radical versus incremental innovations. This is rather surprising, given that radical innovation is critical for firms' long-term survival and serves as a basis for future innovations [3]. Moreover, the literature argues that radical innovation could be more affected by various obstacles than incremental innovation [3]. Third, another relevant aspect is the degree of radicalness in radical innovation. Namely, not only that we can distinguish between radical and incremental innovation, but also, radical innovation is further categorized into innovation new to the world and innovation new to the market. For a detailed discussion on the definition and categorization of radical innovation, see Sandberg and Aarikka-Stenroos [3]. For the same definitions of radical and incremental innovations as in our study, see Doran and Ryan [13]. However, we do not limit our analysis to radical innovation, but also include incremental innovation, given that many firms focus their innovative efforts on incremental innovation [14]). Moreover, we want to explore whether barriers to innovation have a heterogeneous effect on radical compared to incremental innovation.

Our empirical analysis is based on the Mannheim Innovation Panel (MIP) 2017, covering the period 2014-2016. The MIP is the German contribution to the Community Innovation Survey (CIS) and it is an annual survey providing information about innovation activities of German firms. To avoid selection bias, we analyse potentially innovative firms, i.e., firms that are either innovative or those that are willing and try to innovate [15]. Studies have shown that innovation policy for potentially innovative firms should be differentiated from policy instruments aimed at encouraging firms, for which innovation is not a concern, to become potential innovators [15]. Our empirical findings from probit models indicate that financial barriers do not hamper radical innovation, but knowledge and competition barriers do. For incremental innovation, financial and knowledge barriers significantly reduce firms' propensity to innovate.

This study is organized as follows. The next section discusses the theoretical framework and previous empirical evidence on barriers to innovation. It is followed by a description of the sample and data, as well as of the empirical strategy applied in the study. Empirical findings will then be presented. The study concludes by outlining policy implications as well as directions for future research.

\section{Literature Review}

Within the stream of research that investigates barriers to innovation, there are two further complementary lines of enquiry. The first investigates the effects of barriers on innovation performance, while the second looks at the determinants of barriers, such as various firm and market characteristics [5,16]). Studies in the first category have barriers as independent variables, while those in the second category have barriers as dependent variables. Our study belongs to the first group. Until recently, this line of research was mainly focused on financial barriers (as noted in [1,2,6,15-17]). However, recent studies draw attention to non-financial barriers, such as knowledge, demand and market barriers $[2,4]$ ). Besides the dichotomy of financial and non-financial barriers, there is an additional dichotomy of deterring barriers (those faced by non-innovating firms) and revealed barriers (those faced by potentially innovative firms, that tried to innovate but failed to transform innovation inputs into outputs) $[15,17,18])$. Deterring barriers prevents firms from innovating, whereas revealed barriers occur when firms innovate despite facing various barriers. Our study focuses on revealed financial and non-financial barriers, in particular knowledge and competition barriers among innovative and potentially innovative German firms.

Knowledge barriers are primarily associated with a limited firm-level absorptive capacity [19]), given that it is defined as a firm's ability to absorb and utilize information and knowledge relevant to innovation activities [7]. However, knowledge barriers are not limited to firms' absorptive capacity, but rather, with the development of open innovation 
practices, collaboration with external partners becomes equally important $[20,21])$. Consequently, in empirical studies, knowledge barriers are proxied by the lack of qualified personnel and difficulties in findings' cooperative partners (see e.g., $[2,4,7,8]$ ).

Concerning competition barriers, the economics literature on competition and innovation often explores this relationship in different market settings (oligopoly based on price, oligopoly based on quantity, symmetric versus non-symmetric firms, etc.). While early empirical evidence suggested that stronger competition had a detrimental effect on firms' uptake of innovation, studies from the 1990s onwards indicated the opposite (for a review, see [22]). These divergent findings were partially reconciled when Aghion et al. [9] reported an inverted U-shaped relationship; the degree of competition had a positive effect on innovation, but up to a saturation point, after which competition negatively affected innovation.

Our study has the objective of investigating the impact of barriers on innovation activities. Empirical results will show whether these effects are negative, and thus in line with the expectations, or if divergent results will emerge. With respect to the degree of radicalness, Sandberg and Aarikka-Stenroos [3] argue that barriers to radical innovation would differ from those to incremental innovation, as enhanced market and technological uncertainties, inherent to radical innovation, would enhance other types of barriers, such as those related to knowledge and network management. Therefore, we would expect the magnitude of barriers, in particular, related to knowledge management, to be higher for radical than for incremental innovations.

With respect to the review of previous empirical findings, we focus only on studies in which barriers to innovation are independent variables of interest, as they are directly comparable to our study (see Table 1 for a review of studies). Hewitt-Dundas [23] examines the potentially detrimental effects of internal barriers to product innovation in Irish SMEs. Internal barriers include lack of finance, lack of cooperative partners, risk of development and lack of expertise. Empirical results suggest that for small plants, the most important barrier to product innovation is a lack of external partners, whereas for larger plants, it is the high risk of development or a lack of internal expertise. Segarra-Blasco et al. [24] analyse the impact of costs of innovation projects and the lack of knowledge and market conditions in Catalonian firms. Empirical evidence suggests that cost and knowledge barriers seem to be the most important and that there are substantial sectoral differences concerning barriers to innovation. Madrid-Guijarro et al. [25] investigate the impact of 15 obstacles to product, process and management innovations in Spanish SMEs. Findings indicate that the most significant barriers are associated with costs, whereas the least significant are associated with manager/employee resistance. Moreover, costs associated with innovation have proportionately greater impact on small than on larger firms. Blanchard et al. [15] distinguish between financial and non-financial deterring and revealed barriers to innovation. They report that non-financial barriers are equally important as financial barriers. Moreover, innovation policy instruments for supporting potential innovators (firms that either innovate or are willing to innovate) should be differentiated from instruments aimed at encouraging firms that are, for various reasons, not interested in innovation. Amara et al. [26] investigate the impacts of obstacles on various types of innovation in knowledge-intensive business services (KIBS) in Canada. Empirical findings from the logit models suggest that financial obstacles are negatively related to product and process innovations, while knowledge obstacles tend to be negatively associated with delivery, strategic, managerial, and marketing innovations. Finally, Pellegrino and Savona [2] investigate four waves of the UK CIS surveys and report that demand-side factors, particularly concentrated market structure and lack of demand, are as important as financial constraints in lowering the propensity to innovate. 
Table 1. Summary of previous empirical evidence.

\begin{tabular}{|c|c|c|c|}
\hline Authors & Sample & Types of Barriers & Findings \\
\hline \multirow{4}{*}{ Hewitt-Dundas (2006) } & \multirow{4}{*}{ Irish SMEs } & \multirow{4}{*}{$\begin{array}{l}\text { Internal barriers } \\
\text { - lack of finance } \\
\text { - } \quad \text { lack of cooperative partners } \\
\text { risk of development lack of expertise }\end{array}$} & Small plants \\
\hline & & & $\begin{array}{l}\text { - the most important barrier to } \\
\text { product innovation is a lack of } \\
\text { external partners }\end{array}$ \\
\hline & & & Larger plants \\
\hline & & & $\begin{array}{l}\text { - high risk of development or a } \\
\text { lack of internal expertise }\end{array}$ \\
\hline
\end{tabular}

\section{Cost barriers}

- lack of internal funds

- lack of external funds

- $\quad$ high cost of innovation

Knowledge barriers

Segarra-Blasco et al. (2008)

Catalonian firms
Spanish SMEs
- $\quad$ lack of qualified personnel

- lack of information on technology

- lack of information on marketsn

- barriers to finding partners

Market barriers

- market dominated by incumbents

- uncertain demand

- lack of demand for innovation

\section{5 barriers}

- $\quad$ excessive risk

- $\quad$ high costs

- difficulty of controlling cost

- difficulty of access to financial resources

- economic turbulence

- lack of market information

- lack of cooperation possibilities

- lack of regional infrastructures

- $\quad$ insufficient government support

- lack of new technology information

- manager resistance to change

- employee resistance to change

- lack of qualified personnel

- lack of formative activity in the company

- $\quad$ problems of retention of qualified employees in the company
- $\quad$ Cost and knowledge barriers are the most important

- Substantial sectoral differences
Dummy variable $=1$ if a firm has declared having met an obstacle that hampered its willingness to innovate (any nine obstacles: lack of funds within enterprise or group; lack of finance from sources outside enterprise; innovation costs are too high; lack of qualified personnel; lack of information on technology; lack of information on markets; difficulty in finding cooperation partners for innovation; market dominated by established enterprises; uncertain demand for innovative goods or services).
- Cost barriers are the most significant.

- The least significant barriers are associated with manager/employee resistance.

- Costs associated with innovation have proportionately greater impact on small than on larger firms.
Blanchard et al. (2013)

French firms
- Non-financial barriers are equally important as financial barriers.

- Innovation policy instruments for supporting potential innovators should be

differentiated from instruments aimed at encouraging firms that are not interested in innovation. 
Table 1. Cont.

\begin{tabular}{|c|c|c|c|}
\hline Authors & Sample & Types of Barriers & Findings \\
\hline Amara et al. (2016) & $\begin{array}{l}\text { Knowledge-intensive } \\
\text { business services (KIBS) } \\
\text { in Canada }\end{array}$ & $\begin{array}{l}\text { Financial obstacles } \\
\text { - } \quad \text { high economic risk } \\
-\quad \text { cost of financing } \\
\text { Knowledge obstacles } \\
\text { - lack of access to skilled employees } \\
\text { - lack of information on markets } \\
-\quad \text { lack of information on technologies } \\
\text { intensity of competition }\end{array}$ & $\begin{array}{l}\text { - Financial obstacles are } \\
\text { negatively related to product } \\
\text { and process innovations. } \\
\text { Knowledge obstacles are } \\
\text { negatively associated with } \\
\text { delivery, strategic, managerial, } \\
\text { and marketing innovations. }\end{array}$ \\
\hline Pellegrino and Savona (2017) & UK firms & 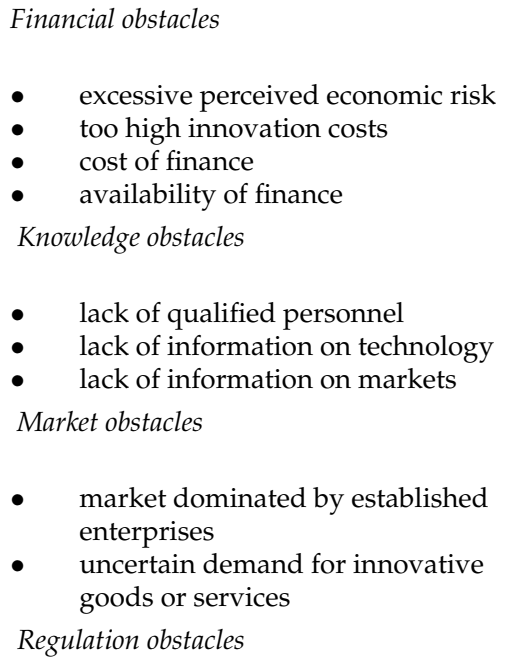 & $\begin{array}{l}\text { Demand-side factors, particularly } \\
\text { concentrated market structure and } \\
\text { lack of demand, are as important as } \\
\text { financial constraints in lowering the } \\
\text { propensity to innovate. }\end{array}$ \\
\hline
\end{tabular}

\section{Methodology}

\subsection{Sample}

The Mannheim Innovation Panel (MIP) dataset used in this study has been collected by the Centre of European Economic Research together with the Fraunhofer Institute for System and Innovation Research and the Institute for Applied Social Sciences on behalf of the German Federal Ministry for Education and Research (BMBF). The MIP is an annual innovation survey based on a panel sample of German firms that constitutes the German contribution to the European Commission's Community Innovation Survey (CIS). The MIP sample is a stratified random sample that covers enterprises with five or more employees from manufacturing and service sectors. The sample is stratified by sector, size, class and region. The MIP is the mail survey.

Our study focuses on the survey conducted in 2017 and covering the period 2014-2016. The MIP questionnaire is divided into 13 groups of questions. The first group provides general information about the firm (number of employees and those with a university degree, turnover and exports), the type of geographical market (regional, national, European and world), firms' strategies and competitive positions. Groups 2 and 3 deal with the introduction of product and process innovations. The main questions of interest for us here are Questions 2.3 and 2.4: "Were any of the product innovations introduced during 2014 to 2016 new to the market, i.e., your enterprise was the first one to market these products/services?" (radical innovation-Question 2.3) and "Were any of the product innovations introduced during the three years 2014 to 2016 new to your enterprise's product range, i.e., there was no previous version of this product in your enterprise's product line?" (incremental innovation-Question 2.4). Group 4 is devoted to ongoing, discontinued, abandoned and planned innovation activities. Group 5 concerns the innovation inputs, particularly internal $R \& D$, external $R \& D$, and the acquisition of other external knowledge 
(embodied in equipment, software, or other sources). Group 6 focuses on public financial support to R\&D and innovation. Group 7 is about the sources of information from customers, suppliers, competitors, etc. Group 8 of the questionnaire is related to cooperation for innovation, types of cooperative partners and their geographical locations. Group 9 is devoted to marketing and organisational innovations. Group 10 deals with intellectual property rights. Group 11 is about two types of factors, those that affect firms' decision to refrain from innovation activities and those that hamper innovation. Our variables of interest are from the second type of factors. Group 12 is about logistic innovation and group 13 focuses on basic financial information (e.g., payroll costs, expenditures for material and intermediate inputs and energy, expenditures for professional development training etc.).

The full sample consists of 5189 firms in manufacturing and service sectors. However, recent empirical studies in this stream of research have made a distinction between innovative, non-innovative and potentially innovative firms [5]. When investigating the influence of barriers to innovation, researchers should take into account the issue of selection bias, given that the CIS waves include innovating and non-innovating firms $[2,4,17])$. Namely, policy instruments for supporting innovation should be designed based on evidence from analysing either innovative firms or those that want to innovate-termed "potential innovators" $[2,4,15,17]$. Accordingly, our sample includes innovating firms as well as potential innovators, i.e., firms who are willing to innovate and face at least one obstacle to innovation at a high degree [15]. Accordingly, we exclude firms that are not innovating and those firms that did not face any obstacles to innovation to a high degree [15]. For each type of barriers, firms are asked whether they face it to a high, medium or low degree (or not important).

Table 2 shows variable description and descriptive statistics for the variables in estimated models. As expected, the number of firms that introduced radical innovation is significantly lower than the number of firms engaged in incremental innovation. In the surveyed period, 34.1 percent of firms introduced innovation new to the world, 26.3 percent of firms introduced innovation new to the market, and 66 percent introduced incremental innovation. On average, the score for financial barriers is 0.443 , for knowledge barriers is 0.454 , and for competition barriers the score is 0.523 . The modal firm in the effective sample has 100 employees, while labour productivity is 27.37 percent. The share of turnover from abroad is 17.66 percent. R\&D intensity on average is 2.05 percent. With respect to the number of firms that invested in various innovation inputs, $42 \%$ of firms invested in machinery and facilities for innovation, $13.9 \%$ invested in external knowledge, $36.8 \%$ in training for innovation, $26.8 \%$ of firms invested in market introduction of innovation, $22.9 \%$ of firms invested in design for innovation, and $34 \%$ of firms invested in conceptual work, industrial engineering associated with innovation.

\subsection{Model Specification}

We estimate three models in which dependent variables are binary indicators (see Table 2 for variable description): the dependent variable Radical innovation new to world is equal to 1 if a firm introduced any products that were new to the world in the period 2014-2016 (zero otherwise); Radical innovation new to market is equal to 1 if a firm introduced new products that are new to the market in the period 2014-2016 (zero otherwise); and Incremental innovation is equal to 1 if a firm introduced a products that are new to the firm in the period 2014-2016 (zero otherwise) (see [13] for these definitions). Given that all three dependent variables are binary, we will estimate probit models (see Table 3). 
Table 2. Variable description and summary statistics.

\begin{tabular}{|c|c|c|}
\hline Variables & Variable Description & $\begin{array}{c}\text { Mean } \\
\text { (Stand. Deviation) }\end{array}$ \\
\hline \multicolumn{3}{|l|}{ Dependent variables } \\
\hline Radical new to world & $\begin{array}{l}\text { DV = } 1 \text { if a firm responded "Yes" to question: "Were any of the product innovations } \\
\text { introduced during } 2014 \text { to } 2016 \text { new to the world market?"; zero otherwise }\end{array}$ & $\begin{array}{c}0.341 \\
(0.474)\end{array}$ \\
\hline Radical new to market & $\begin{array}{l}\text { DV = } 1 \text { if a firm responded "Yes" to question: "Were any of the product innovations } \\
\text { introduced during } 2014 \text { to } 2016 \text { new to the market?"; zero otherwise }\end{array}$ & $\begin{array}{c}0.263 \\
(0.441)\end{array}$ \\
\hline Incremental innovation & $\begin{array}{l}\text { DV = } 1 \text { if a firm responded "Yes" to question: "Were any of the product innovations } \\
\text { introduced during the three years } 2014 \text { to } 2016 \text { new to your enterprise's product } \\
\text { range, i.e., there was no previous version of this product in your enterprise's } \\
\text { product line?"; zero otherwise }\end{array}$ & $\begin{array}{c}0.660 \\
(0.474)\end{array}$ \\
\hline \multicolumn{3}{|l|}{ Variables of interest } \\
\hline Financial barriers & $\begin{array}{l}\text { Score }=(\text { cost barrier }+ \text { lack of internal finance }+ \text { lack of external finance }+ \text { barrier to } \\
\text { government support }) / 4\end{array}$ & $\begin{array}{c}0.443 \\
(0.383)\end{array}$ \\
\hline Knowledge barriers & $\begin{array}{l}\text { Score }=(\text { lack of internal skilled employees }+ \text { lack of skilled external employees }+ \\
\text { lack of collaborative partners }) / 3\end{array}$ & $\begin{array}{c}0.454 \\
(0.377)\end{array}$ \\
\hline Competition barriers & $\begin{array}{l}\text { Score }=(\text { product substitutes }+ \text { threat of entrants }+ \text { competitor behaviour }+ \text { foreign } \\
\text { competitors }+ \text { price increase }) / 5\end{array}$ & $\begin{array}{c}0.523 \\
(0.311)\end{array}$ \\
\hline \multicolumn{3}{|l|}{ Control variables } \\
\hline Firm size & Number of employees in 2014 & $\begin{array}{c}99.593 \\
(168.683)\end{array}$ \\
\hline Labour productivity & Turnover divided by number of employees in 2014 & $\begin{array}{c}27.367 \\
(16.769)\end{array}$ \\
\hline Export intensity & Turnover from abroad divided by total turnover in 2014 & $\begin{array}{c}17.655 \\
(25.749)\end{array}$ \\
\hline R\&D intensity & R\&D expenditure divided by turnover in 2016 & $\begin{array}{c}2.053 \\
(4.139)\end{array}$ \\
\hline Machines and facilities & $\begin{array}{l}\text { DV = } 1 \text { if a firm invested in acquisition of machinery, equipment, software and } \\
\text { buildings for innovation in the period 2014-2016; zero otherwise }\end{array}$ & $\begin{array}{l}0.420 \\
(0.494)\end{array}$ \\
\hline External knowledge & $\begin{array}{l}\text { DV = } 1 \text { if a firm invested in acquisition of other external knowledge for innovation } \\
\text { in the period 2014-2016; zero otherwise }\end{array}$ & $\begin{array}{c}0.139 \\
(0.346)\end{array}$ \\
\hline Training & $\begin{array}{l}\text { DV = } 1 \text { if a firm invested in in-house and external training for innovation in the } \\
\text { period 2014-2016; zero otherwise }\end{array}$ & $\begin{array}{c}0.368 \\
(0.482)\end{array}$ \\
\hline Market introduction & $\begin{array}{l}\text { DV = } 1 \text { if a firm invested in market introduction of innovation (in-house and } \\
\text { externally procured marketing activities in direct connection to product or process } \\
\text { innovation) in the period 2014-2016; zero otherwise }\end{array}$ & $\begin{array}{c}0.268 \\
(0.443)\end{array}$ \\
\hline Design & $\begin{array}{l}\text { DV = } 1 \text { if a firm invested in design for innovation (in-house and externally procured } \\
\text { design activities in direct connection to product or process innovation) in the period } \\
\text { 2014-2016; zero otherwise }\end{array}$ & $\begin{array}{c}0.229 \\
(0.420)\end{array}$ \\
\hline Preparation & $\begin{array}{l}\text { DV = } 1 \text { if a firm invested in conceptual work, industrial engineering and other } \\
\text { activities for innovations in the period 2014-2016; zero otherwise }\end{array}$ & $\begin{array}{l}0.340 \\
(0.474)\end{array}$ \\
\hline Food or tobacco & $\mathrm{DV}=1$ if a sector in which a firm is operating is food or tobacco; zero otherwise & $\begin{array}{c}0.051 \\
(0.220)\end{array}$ \\
\hline Textiles & $\mathrm{DV}=1$ if a sector in which a firm is operating is textiles; zero otherwise & $\begin{array}{c}0.036 \\
(0.187)\end{array}$ \\
\hline Wood or paper & DV = 1 if a sector in which a firm is operating is wood or paper; zero otherwise & $\begin{array}{c}0.027 \\
(0.163)\end{array}$ \\
\hline Chemicals & DV = 1 if a sector in which a firm is operating is chemicals; zero otherwise & $\begin{array}{c}0.051 \\
(0.220)\end{array}$ \\
\hline Plastics & $\mathrm{DV}=1$ if a sector in which a firm is operating is plastics; zero otherwise & $\begin{array}{l}0.040 \\
(0.197)\end{array}$ \\
\hline Glass or ceramics & DV = 1 if a sector in which a firm is operating is glass or ceramics; zero otherwise & $\begin{array}{c}0.016 \\
(0.125)\end{array}$ \\
\hline Metals & $\mathrm{DV}=1$ if a sector in which a firm is operating is metals; zero otherwise & $\begin{array}{c}0.080 \\
(0.272)\end{array}$ \\
\hline
\end{tabular}


Table 2. Cont.

\begin{tabular}{|c|c|c|}
\hline Variables & Variable Description & $\begin{array}{l}\text { Mean } \\
\text { (Stand. Deviation) }\end{array}$ \\
\hline Electric equipment & $\mathrm{DV}=1$ if a sector in which a firm is operating is electric equipment; zero otherwise & $\begin{array}{c}0.099 \\
(0.298)\end{array}$ \\
\hline Machinery & $\mathrm{DV}=1$ if a sector in which a firm is operating is machinery; zero otherwise & $\begin{array}{c}0.071 \\
(0.257)\end{array}$ \\
\hline Retail or automotive & $\begin{array}{l}\text { DV = } 1 \text { if a sector in which a firm is operating is sale, maintenance and repair of } \\
\text { motor vehicles and motorcycles, retail sale of automotive fuel; retail trade, repair of } \\
\text { personal and household goods; zero otherwise }\end{array}$ & $\begin{array}{c}0.026 \\
(0.160)\end{array}$ \\
\hline Furniture & $\begin{array}{l}\mathrm{DV}=1 \text { if a sector in which a firm is operating is manufacturing of furniture, jewelry, } \\
\text { musical instruments, sports equipment, games and toys; zero otherwise }\end{array}$ & $\begin{array}{c}0.070 \\
(0.254)\end{array}$ \\
\hline Energy and water & $\begin{array}{l}\text { DV = } 1 \text { if a sector in which a firm is operating is electricity, gas and water supply; } \\
\text { zero otherwise }\end{array}$ & $\begin{array}{c}0.030 \\
(0.170)\end{array}$ \\
\hline Wholesale & $\begin{array}{l}\mathrm{DV}=1 \text { if a sector in which a firm is operating is wholesale trade and commission } \\
\text { trade, except of motor vehicles and motorcycles; zero otherwise }\end{array}$ & $\begin{array}{c}0.032 \\
(0.175)\end{array}$ \\
\hline Transport equipment & $\begin{array}{l}\mathrm{DV}=1 \text { if a sector in which a firm is operating is manufacturing of motor vehicles } \\
\text { and parts, other transport equipment, aircraft and spacecraft; zero otherwise }\end{array}$ & $\begin{array}{c}0.073 \\
(0.260)\end{array}$ \\
\hline Media services & $\mathrm{DV}=1$ if a sector in which a firm is operating is media services; zero otherwise & $\begin{array}{c}0.043 \\
(0.203)\end{array}$ \\
\hline IT & $\begin{array}{l}\mathrm{DV}=1 \text { if a sector in which a firm is operating is computer and related activities, } \\
\text { telecommunications; zero otherwise }\end{array}$ & $\begin{array}{c}0.056 \\
(0.231)\end{array}$ \\
\hline Banking and insurance & $\begin{array}{l}\text { DV = } 1 \text { if a sector in which a firm is operating is banking and insurance; zero } \\
\text { otherwise }\end{array}$ & $\begin{array}{c}0.026 \\
(0.158)\end{array}$ \\
\hline Technical and R\&D services & $\begin{array}{l}\mathrm{DV}=1 \text { if a sector in which a firm is operating is research \& development; } \\
\text { architectural and engineering activities; technical, physical and chemical testing and } \\
\text { analysis; zero otherwise }\end{array}$ & $\begin{array}{c}0.068 \\
(0.251)\end{array}$ \\
\hline Consulting and advertising & $\begin{array}{l}\text { DV }=1 \text { if a sector in which a firm is operating is consulting and advertising; zero } \\
\text { otherwise }\end{array}$ & $\begin{array}{c}0.064 \\
(0.245)\end{array}$ \\
\hline Firm-related services & $\begin{array}{l}\mathrm{DV}=1 \text { if a sector in which a firm is operating is legal, accounting, book-keeping and } \\
\text { auditing activities, tax consultancy, market research and public opinion polling, } \\
\text { holdings; zero otherwise }\end{array}$ & $\begin{array}{c}0.041 \\
(0.197)\end{array}$ \\
\hline
\end{tabular}

Regarding explanatory variables of interest, individual barriers to innovation are measured on a four-item scale that asks firms to evaluate the importance of a specific barrier ("no", "low", "medium", "high"). The survey question is: "How important were the following hampering factors for starting and conducting innovation activities in your enterprise during 2014 and 2016?". Responses were recoded into binary variables equal to zero if a barrier was not important or rated as having a low importance and equal to 1 if it was considered of medium or high importance. After individual barriers were created, we further grouped them into three categories-financial, knowledge and competition barriers. Each category is measured as a score, and formulas for each are shown in Table 2 (see [27], on constructing this type of scores in a different context). Financial barriers include "Innovation costs too high", "Lack of internal finance for innovation", "Lack of external finance for innovation", and "Difficulties in obtaining government grants or subsidies for innovation". Knowledge barriers include "Lack of skilled employees within the enterprise", "Lack of skilled employees in the labour market", and "Lack of suitable collaboration partners". Competition barriers include "Products/services are easily substituted by competitors' products/services", "Major threat to market position because of entry of new competitors", "Competitor's actions are difficult to predict", "Strong competition from abroad", and "Price increases lead to immediate loss of clients". 
Table 3. Probit model estimations.

\begin{tabular}{|c|c|c|c|}
\hline & Model 1 & Model 2 & Model 3 \\
\hline Independent Variables & $\begin{array}{l}\text { Radical Innovation } \\
\text { New to World }\end{array}$ & $\begin{array}{c}\text { Radical Innovation } \\
\text { New to Market }\end{array}$ & $\begin{array}{c}\text { Incremental } \\
\text { Innovation }\end{array}$ \\
\hline Financial barriers & $\begin{array}{c}0.070 \\
(0.132)\end{array}$ & $\begin{array}{c}0.082 \\
(0.139)\end{array}$ & $\begin{array}{c}-0.441^{* * *} \\
(0.153)\end{array}$ \\
\hline Knowledge barriers & $\begin{array}{c}-0.338^{* * *} \\
(0.127)\end{array}$ & $\begin{array}{c}-0.133 \\
(0.135)\end{array}$ & $\begin{array}{c}-0.548^{* * *} \\
(0.154)\end{array}$ \\
\hline Competition barriers & $\begin{array}{c}-0.307^{* *} \\
(0.145)\end{array}$ & $\begin{array}{c}-0.320 \text { ** } \\
(0.149)\end{array}$ & $\begin{array}{c}-0.274 \\
(0.178)\end{array}$ \\
\hline Firm size & $\begin{array}{c}0.001^{* *} \\
(0.000)\end{array}$ & $\begin{array}{c}0.000 \\
(0.000)\end{array}$ & $\begin{array}{l}0.001 \text { * } \\
(0.000)\end{array}$ \\
\hline Productivity & $\begin{array}{c}0.005 \\
(0.003)\end{array}$ & $\begin{array}{l}0.006^{*} \\
(0.003)\end{array}$ & $\begin{array}{c}0.002 \\
(0.004)\end{array}$ \\
\hline Export intensity & $\begin{array}{c}0.001 \\
(0.002)\end{array}$ & $\begin{array}{c}0.003 \\
(0.002)\end{array}$ & $\begin{array}{c}0.007^{* *} \\
(0.003)\end{array}$ \\
\hline R\&D intensity & $\begin{array}{c}0.044^{* * *} \\
(0.012)\end{array}$ & $\begin{array}{c}0.083^{* * * *} \\
(0.013)\end{array}$ & $\begin{array}{c}0.084^{* * * *} \\
(0.029)\end{array}$ \\
\hline Machines and facilities & $\begin{array}{l}0.196^{*} \\
(0.100)\end{array}$ & $\begin{array}{c}0.004 \\
(0.111)\end{array}$ & $\begin{array}{c}1.288^{* * *} \\
(0.148)\end{array}$ \\
\hline External knowledge & $\begin{array}{c}0.144 \\
(0.128)\end{array}$ & $\begin{array}{c}0.318^{* *} \\
(0.133)\end{array}$ & $\begin{array}{c}0.749 * * \\
(0.294)\end{array}$ \\
\hline Training & $\begin{array}{c}0.442 * * * \\
(0.107)\end{array}$ & $\begin{array}{l}-0.098 \\
(0.119)\end{array}$ & $\begin{array}{c}0.691 * * * \\
(0.186)\end{array}$ \\
\hline Market introduction & $\begin{array}{c}0.480 * * * \\
(0.119)\end{array}$ & $\begin{array}{c}0.625^{* * *} \\
(0.125)\end{array}$ & $\begin{array}{c}1.230 * * * \\
(0.330)\end{array}$ \\
\hline Design & $\begin{array}{l}-0.004 \\
(0.125)\end{array}$ & $\begin{array}{c}0.374^{* * *} \\
(0.125)\end{array}$ & $\begin{array}{c}0.143 \\
(0.264)\end{array}$ \\
\hline Preparation & $\begin{array}{c}0.312^{* * *} \\
(0.117)\end{array}$ & $\begin{array}{l}0.228^{*} \\
(0.123)\end{array}$ & $\begin{array}{c}0.874^{* * *} \\
(0.183)\end{array}$ \\
\hline Constant & $\begin{array}{c}-0.937^{* * *} \\
(0.227)\end{array}$ & $\begin{array}{c}-1.426^{* * *} \\
(0.269)\end{array}$ & $\begin{array}{c}-0.263 \\
(0.256)\end{array}$ \\
\hline No of observations & 1136 & 1142 & 1139 \\
\hline
\end{tabular}

Notes: Sectoral dummies are included in all models but not reported. Robust standard errors in parentheses. ${ }_{* * *} p<0.01,{ }^{* *} p<0.05, * p<0.1$.

Control variables include continuous variables Firm size to account for the number of employees and Productivity (defined as turnover divided by number of employees in 2014). We model exporting activities (variable Export) as a continuous variable, measuring the share of total sales sold abroad in 2014. Exporting firms might be more innovative than their counterparts, as international competition creates more pressure on firms to innovate $[28,29]$. With respect to absorptive capacity, we include a series of variables capturing firms' activities as innovation inputs: a continuous variable $R \& D$ intensity $(R \& D$ expenditure divided by turnover in 2016) (see, e.g., [29]); and dummy variables Machines and facilities (investment in acquisition of machinery, equipment, software and buildings), External knowledge (investment in acquisition of other external knowledge for innovation), Training (investment in in-house and external training for innovation) (see, e.g., [30]), Market introduction (investment in market introduction of innovation) (see, e.g., [30]), Design (investment in design for innovation) and Preparation (investment in conceptual work, industrial engineering and other activities for innovations). Finally, to control for industry heterogeneity, sectorial dummy variables were included for 20 industries (mining is excluded from the analysis; food or tobacco is the reference sector, see Table 2 for the list of sectors).

\section{Empirical Results}

The correlation matrix showing the Pearson correlation coefficients among the independent variables is presented in Table A1 in Appendix A. Following Hair et al. [31] 
(p. 351), correlation coefficients below 0.40 suggests a small strength of association between variables, between 0.40 and 0.70 a moderate association, and above 0.70 high association. Therefore, the correlations shown in Table A1 are overall small to moderate. To assess potential problems with multicollinearity, the variance inflation factor (VIF) was calculated for models shown in Table 2. The VIF is 1.76, which is substantially lower than the conservative cut-off of 10 [32]. These results suggest that the estimated models are not biased by the presence of multicollinearity.

Estimated probit models are reported in Table 3. In Model 1, in which the dependent variable is radical innovation that is new to the world, knowledge and competition barriers have negative and statistically significant ( $p<0.01$ and $p<0.05$ respectively) effects. To quantitatively interpret the results, we proceed by estimating marginal effects (see Table 4). Knowledge barriers reduce the propensity to radical innovation that is new to the world by 9.2 percentage points (p.p.), while competition barriers reduce it by 8.4 p.p. In Model 2 , in which the dependent variable is radical innovation that is new to the market, the impact of competition barriers is negative and statistically significant $(p<0.05)$, while we find no evidence of the impact of financial and knowledge barriers. Marginal effects in Table 4 show that competition barriers reduce the probability of radical innovation that is new to the market by 7.7 p.p. Finally, in Model 3, in which the dependent variable is incremental innovation, financial and knowledge barriers have negative and highly statistically significant $(p<0.01)$ effects. Marginal effects in Table 4 show that financial barriers reduce the propensity to incremental innovation by 7.2 p.p., whereas knowledge barriers reduce it by 9 p.p.

Table 4. Marginal effects for models in Table 3.

\begin{tabular}{|c|c|c|c|}
\hline & Model 1 & Model 2 & Model 3 \\
\hline Independent Variables & $\begin{array}{c}\text { Radical New to } \\
\text { World }\end{array}$ & $\begin{array}{c}\text { Radical New to } \\
\text { Market }\end{array}$ & $\begin{array}{l}\text { Incremental } \\
\text { Innovation }\end{array}$ \\
\hline Financial barriers & $\begin{array}{c}0.019 \\
(0.036)\end{array}$ & $\begin{array}{c}0.020 \\
(0.034)\end{array}$ & $\begin{array}{c}-0.072 * * * \\
(0.025)\end{array}$ \\
\hline Knowledge barriers & $\begin{array}{c}-0.092 * * * \\
(0.034)\end{array}$ & $\begin{array}{l}-0.032 \\
(0.033)\end{array}$ & $\begin{array}{c}-0.090^{* * *} \\
(0.025)\end{array}$ \\
\hline Competition barriers & $\begin{array}{c}-0.084 \text { ** } \\
(0.039)\end{array}$ & $\begin{array}{c}-0.077^{* *} \\
(0.036)\end{array}$ & $\begin{array}{l}-0.045 \\
(0.029)\end{array}$ \\
\hline Firm size & $\begin{array}{c}0.000 * * \\
(0.000)\end{array}$ & $\begin{array}{c}0.000 \\
(0.000)\end{array}$ & $\begin{array}{l}0.000 \text { * } \\
(0.000)\end{array}$ \\
\hline Productivity & $\begin{array}{c}0.001 \\
(0.001)\end{array}$ & $\begin{array}{l}0.001 \text { * } \\
(0.001)\end{array}$ & $\begin{array}{c}0.000 \\
(0.001)\end{array}$ \\
\hline Export intensity & $\begin{array}{c}0.000 \\
(0.001)\end{array}$ & $\begin{array}{c}0.001 \\
(0.001)\end{array}$ & $\begin{array}{c}0.001 * * \\
(0.001)\end{array}$ \\
\hline R\&D intensity & $\begin{array}{c}0.012 * * * \\
(0.003)\end{array}$ & $\begin{array}{c}0.020^{* * * *} \\
(0.003)\end{array}$ & $\begin{array}{c}0.014^{* * *} \\
(0.005)\end{array}$ \\
\hline Machines and facilities & $\begin{array}{l}0.053 \text { * } \\
(0.027)\end{array}$ & $\begin{array}{c}0.001 \\
(0.027)\end{array}$ & $\begin{array}{c}0.212^{* * *} \\
(0.021)\end{array}$ \\
\hline External knowledge & $\begin{array}{c}0.039 \\
(0.035)\end{array}$ & $\begin{array}{c}0.077^{* *} \\
(0.032)\end{array}$ & $\begin{array}{c}0.123 \text { ** } \\
(0.048)\end{array}$ \\
\hline Training & $\begin{array}{c}0.121^{* * *} \\
(0.029)\end{array}$ & $\begin{array}{l}-0.024 \\
(0.029)\end{array}$ & $\begin{array}{c}0.114^{* * *} \\
(0.029)\end{array}$ \\
\hline Market introduction & $\begin{array}{c}0.131^{* * *} \\
(0.032)\end{array}$ & $\begin{array}{l}0.151^{* * *} \\
(0.029)\end{array}$ & $\begin{array}{l}0.202^{* * *} \\
(0.054)\end{array}$ \\
\hline Design & $\begin{array}{l}-0.001 \\
(0.034)\end{array}$ & $\begin{array}{c}0.090 * * * \\
(0.030)\end{array}$ & $\begin{array}{c}0.023 \\
(0.043)\end{array}$ \\
\hline Preparation & $\begin{array}{c}0.085^{* * *} \\
(0.032)\end{array}$ & $\begin{array}{l}0.055 \text { * } \\
(0.030)\end{array}$ & $\begin{array}{c}0.144^{* * *} \\
(0.029)\end{array}$ \\
\hline No of observations & 1136 & 1142 & 1139 \\
\hline
\end{tabular}


Focusing on control variables, firm size has a positive effect on radical innovation that is new to the world $(p<0.05)$ and marginal positive effect on incremental innovation $(p<0.1)$. Productivity only marginally $(p<0.1)$ increases the likelihood of radical innovation in the market. Exporting firms are more likely to introduce incremental innovation $(p<0.05)$. Concerning absorptive capacity, R\&D intensity uniformly increases the probability of all three types of innovation $(p<0.01)$, while investment in machines and facilities increases the probability of incremental innovation by 21.2 p.p. $(p<0.01)$ and marginally increases the likelihood of radical innovation new to the world by 5.3 p.p. $(p<0.1)$. Investment in external knowledge increases the likelihood of radical innovation that is new to the market by 7.7 p.p. $(p<0.05)$ and incremental innovation by 12.3 p.p. $(p<0.05)$. Training focused on innovation activities increases the propensity of radical innovation that is new to the world by 12.1 p.p. $(p<0.01)$ and of incremental innovation by 11.4 p.p. $(p<0.01)$. Investment in market introduction of innovation has a uniformly positive effect on all three types of innovation (and highly statistically significant, $p<0.01$ ). Investment in design has a positive effect on innovation that is new to the market $(p<0.01)$. Finally, investment in conceptual work and industrial engineering (variable Preparation) has highly statistically significant effects on innovation that is new to the world and incremental innovation $(p<0.01)$ and a marginally positive effect on innovation that is new to the market $(p<0.1)$.

\section{Conclusions}

\subsection{Discussions and Implications}

This study explores barriers to radical and incremental innovations in German firms for the period 2014-2016. Our findings reveal heterogeneous effects with respect to the degree of radicalness. First, competition barriers reduce the propensity to both types of radical innovation, but have no effect on incremental innovation. Second, in Section 2, we noted that the magnitude of barriers, in particular, related to knowledge management, was expected to be higher for radical than for incremental innovations. However, our findings show that knowledge barriers have the same effects on radical innovation (new to the world) and incremental innovation. That is, there is no statistically significant difference at the $1 \%$ level between the coefficients ( 0.092 and 0.090 respectively). Third, with respect to financial barriers, empirical findings indicate that German firms do not perceive them as a hampering factor for the propensity to radical innovation, but they do reduce the likelihood of incremental innovation.

Overall, these findings are partly consistent with Hölzl and Janger [7], who explored the effects of innovation barriers in $18 \mathrm{EU}$ member states that are at different stages of economic and technological development. The authors report that, for firms located in countries close to the economic and technology frontier, the availability of external finance is not a hindering factor, while barriers related to the availability of skilled labour, innovation partners and technological knowledge are important barriers to innovation. These findings can be associated with Germany, given that it is among countries that are innovation leaders in the EU as well as at the technology and economic frontier. However, our analysis provides more fine-grained findings that show that financial barriers indeed are not a significant hampering factor in case of radical innovation. Moreover, we report a significant detrimental effect of knowledge barriers on both types of innovation.

The magnitudes of detrimental effects are economically substantial, such that the smallest effect is 7.2 percentage points in case of the impact of financial barriers to incremental innovation, and the largest is 9.2 percentage points with respect to the influence of knowledge barriers on the likelihood of radical innovation that is new to the world. These effects are consistent with Blanchard et al. [15], who report that the presence of obstacles reduces the propensity to innovate between 8 and 17 percentage points.

Our study offers three contributions to the literature on barriers to innovation. First, empirical results suggest that a "one-size-fits-all" policy is not optimal in supporting radical and incremental innovations, given that firms face different barriers depending on which 
type of innovation they want to engage in. If policy makers want to stimulate firms' engagement in radical innovation, then removing or minimizing knowledge and competition barriers is of high importance. With respect to the latter, the demand-side policy measures could be particularly effective $[1,33]$. Namely, if too much competitive pressure has a detrimental effect on radical innovation, then the government could create its own demand for products that are currently unavailable in the market via, e.g., public procurement of innovation. This policy instrument is complementary to traditional, supply-side measures, such as R\&D subsidies and R\&D tax credits [1,34]. The second contribution is the finding that financial constraints have a hampering effect on the propensity to incremental innovation. Policy measures aimed at addressing this market failure should be accompanied with measures designed to address systemic failures associated with knowledge barriers, such as the education policy and private-public cooperation [6,15]. The third contribution is the finding that common barriers that firms face when introducing any type of innovation, whether radical or incremental, are those related to knowledge generation. Consequently, any policy measures designed to tackle bottlenecks in knowledge provision will have a stimulating effect on innovation, regardless of its degree of radicalness.

\subsection{Limitations and Future Research}

Our study has certain limitations that can serve as suggestions for future research. First, the dataset used in this study is cross-sectional, which means that we cannot explore dynamics of obstacles to innovation [3]. The availability of longitudinal data would allow this line of enquiry, as well as the distinction between short and long run effects. Second, it would be interesting to conduct a more fine-grained analysis based on different types of firms and markets. For instance, it would be insightful to explore whether different types of barriers have a similar detrimental effect in SMEs compared to large firms, and firms operating in the manufacturing sector compared to services firms [3]. Finally, our study focuses on one country, which is an innovation leader in the European Union (see Innovation Scoreboards). Future cross-country comparisons would allow a comparison of our findings for Germany with findings for other countries categorized as innovation leaders in the Innovation Scoreboard, but also for country groups of followers, moderate and modest innovators [7].

Funding: This research received no external funding.

Institutional Review Board Statement: Not applicable.

Informed Consent Statement: Not applicable.

Data Availability Statement: Restrictions apply to the availability of these data. Data was obtained from the Centre for European Economic Research (ZEW) in Germany.

Conflicts of Interest: The author declares no conflict of interest. 


\section{Appendix A}

Table A1. Correlation matrix.

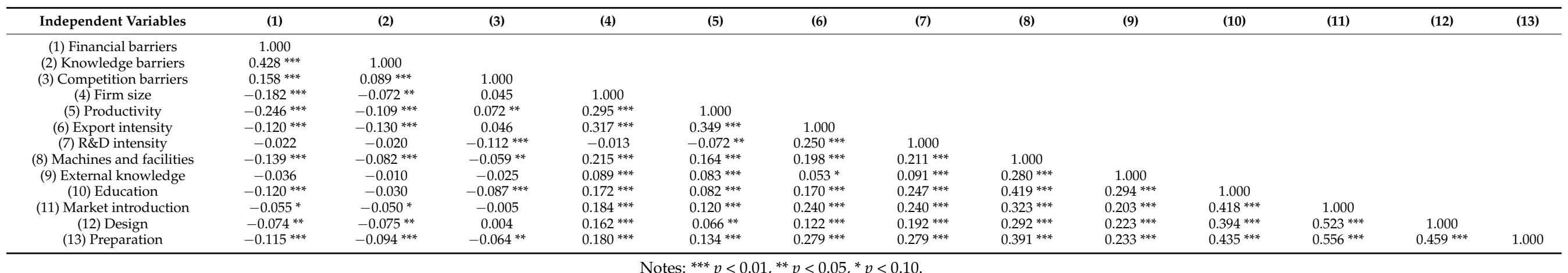




\section{References}

1. García-Quevedo, J.; Pellegrino, G.; Savona, M. Reviving demand-pull perspectives: The effect of demand uncertainty and stagnancy on R\&D strategy. Camb. J. Econ. 2017, 41, 1087-1122.

2. Pellegrino, G.; Savona, M. No money, no honey? Financial versus knowledge and demand constraints on innovation. Res. Policy 2017, 46, 510-521. [CrossRef]

3. Sandberg, B.; Aarikka-Stenroos, L. What makes it so difficult? A systematic review on barriers to radical innovation. Ind. Mark. Manag. 2014, 43, 1293-1305. [CrossRef]

4. D'Este, P.; Rentocchini, F.; Vega-Jurado, J. The Role of Human Capital in Lowering the Barriers to Engaging in Innovation: Evidence from the Spanish Innovation Survey. Ind. Innov. 2014, 21, 1-19. [CrossRef]

5. De-Oliviera, F.; Rodil-Marzábal, O. Structural characteristics and organizational determinants as obstacles to innovation in small developing countries. Tech. Forecast. Soc. Chang. 2019, 140, 306-314. [CrossRef]

6. Coad, A.; Pellegrino, G.; Savona, M. Barriers to innovation and firm productivity. Econ. Innov. New Technol. 2016, 25, 321-334. [CrossRef]

7. Hölzl, W.; Janger, J. Distance to the frontier and the perception of innovation barriers across European countries. Res. Policy 2014, 43, 707-725. [CrossRef]

8. Thomä, J. DUI mode learning and barriers to innovation-A case from Germany. Res. Policy 2017, 46, 1327-1339. [CrossRef]

9. Aghion, P.; Bloom, N.; Blundell, R.; Griffith, R.; Howitt, P. Competition and innovation: An inverted-U relationship. Q. J. Econ. 2005, 120, 701-728.

10. Aghion, P.; Bechtold, S.; Cassar, L.; Herz, H. The Causal Effects of Competition on Innovation: Experimental Evidence. J. Law Econ. Organ. 2018, 34, 162-195. [CrossRef]

11. Hashmi, A.R. Competition and innovation: An inverted-U relationship revisited. Rev. Econ. Stat. 2013, 95, 1653-1668. [CrossRef]

12. Hueske, A.-K.; Guenther, E. What hampers innovation? External stakeholders, the organization, groups and individuals: A systematic review of empirical barrier research. Manag. Rev. Q. 2015, 65, 113-148. [CrossRef]

13. Doran, J.; Ryan, G. Firms' skills as drivers of radical and incremental innovation. Econ. Lett. 2014, 125, 107-109. [CrossRef]

14. Radicic, D.; Pugh, G.; Douglas, D. Promoting cooperation in innovation ecosystems: Evidence from European traditional manufacturing SMEs. Small Bus. Econ. 2020, 54, 257-283. [CrossRef]

15. Blanchard, P.; Huiban, J.-P.; Musolesi, A.; Sevestre, P. Where there is a will, there is a way? Assessing the impact of obstacles to innovation. Ind. Corp. Chang. 2013, 22, 679-710. [CrossRef]

16. Santiago, F.; De Fuentes, C.; Dutrénit, G.; Gras, N. What hinders innovation performance of services and manufacturing firms in Mexico? Econ. Innov. New Technol. 2016, 26, 247-268. [CrossRef]

17. D'Este, P.; Iammarino, S.; Savona, M.; Von Tunzelmann, N. What hampers innovation? Revealed barriers versus deterring barriers. Res. Policy 2012, 41, 482-488. [CrossRef]

18. Mohnen, P.; Palm, F.C.; Van Der Loeff, S.; Tiwari, A. Financial constraints and other obstacles: Are they a threat to innovation activity? Economist 2008, 156, 201-214. [CrossRef]

19. Cohen, W.M.; Levinthal, D.A. Absorptive capacity: A new perspective on learning and innovation. Admin. Sci. Q. 1990, 35, 128-152. [CrossRef]

20. Demirkan, I. The impact of firm resources on innovation. Eur. J. Innov. Manag. 2018, 21, 672-694. [CrossRef]

21. Rossi, M.; Martini, E. Venture capitalists and value creation: The role of informal investors in the growth of smaller European firms. Int. J. Glob. Small Bus. 2019, 10, 233-247. [CrossRef]

22. Moen, Ø.; Tvedten, T.; Wold, A.; Wright, L.T. Exploring the relationship between competition and innovation in Norwegian SMEs. Cogent Bus. Manag. 2018, 5, 1564167. [CrossRef]

23. Hewitt-Dundas, N. Resource and Capability Constraints to Innovation in Small and Large Plants. Small Bus. Econ. 2006, 26, 257-277. [CrossRef]

24. Segarra-Blasco, A.; Garcia-Quevedo, J.; Teruel, M. Barriers to innovation and public policy in Catalonia. Int. Entrep. Manag. J. 2008, 4, 431-451. [CrossRef]

25. Madrid-Guijarro, A.; Garcia, D.; Van Auken, H. Barriers to Innovation among Spanish Manufacturing SMEs. J. Small Bus. Manag. 2009, 47, 465-488. [CrossRef]

26. Amara, N.; D’Este, P.; Landry, R.; Doloreux, D. Impacts of obstacles on innovation patterns in KIBS firms. J. Bus. Res. 2016, 69, 4065-4073. [CrossRef]

27. Cassiman, B.; Veugelers, R. R\&D Cooperation and Spillovers: Some Empirical Evidence from Belgium. Am. Econ. Rev. 2002, 92, 1169-1184. [CrossRef]

28. Nieto, M.; Santamaría, L. Technological collaboration: Bridging the innovation gap between small and large firms. J. Small Bus. Manag. 2010, 48, 44-69. [CrossRef]

29. Radicic, D.; Balavac, M. In-house R\&D, external R\&D and cooperation breadth in Spanish manufacturing firms: Is there a synergistic effect on innovation outputs? Econ. Innov. New Technol. 2018, 28, 590-615. [CrossRef]

30. Parrilli, M.D.; Balavac, M.; Radicic, D. Business innovation modes and their impact on innovation outputs: Regional variations and the nature of innovation across EU regions. Res. Policy 2020, 49, 104047. [CrossRef] 
31. Hair, J.; Black, W.; Babin, B.; Anderson, R.; Tatham, R. Multivariate Data Analysis, 6th ed.; Pearson Prentice Hall: Upper Saddle River, NJ, USA, 2006.

32. Fernández-Olmos, M.; Ramírez-Alesón, M. How internal and external factors influence the dynamics of SME technology collaboration networks over time. Technovation 2017, 64-65, 16-27. [CrossRef]

33. Radicic, D. Effectiveness of public procurement of innovation versus supply-side innovation measures in manufacturing and service sectors. Sci. Public Policy 2019, 46, 732-746. [CrossRef]

34. Guerzoni, M.; Raiteri, E. Demand-side vs. supply-side technology policies: Hidden treatment and new empirical evidence on the policy mix. Res. Policy 2015, 44, 726-747. [CrossRef] 